\title{
Dispersion of human intestinal Geohelminth ova in selected refuse dumpsites in Igbara-Oke, Ifedore, Local Government Area, Ondo State, Nigeria
}

\author{
E. O. Dada ${ }^{1 *}$ and A. A. Egbunu ${ }^{2}$ \\ ${ }_{1}$ Department of Microbiology, Federal University of Technology, P.M.B 704, Akure, Nigeria \\ ${ }^{2}$ Kogi State Polytechnic, Lokoja, Nigeria \\ *Corresponding author
}

\begin{tabular}{|c|c|}
\hline & A B S T R A C T \\
\hline \multirow{4}{*}{$\begin{array}{l}\text { Ke e y o o d s } \\
\text { Dispersion, } \\
\text { Human intestinal, } \\
\text { Geohelminth, } \\
\text { Ova, Refuse, } \\
\text { Dumpsites. }\end{array}$} & \multirow{10}{*}{$\begin{array}{l}\text { This study was carried out to determine the dispersion of human intestinal } \\
\text { geohelminth ova in refuse dumpsites in Igbara-Oke, Ifedore LGA of Ondo State. A } \\
\text { total of } 208 \text { soil samples were collected from different refuse dumpsites. Ova and } \\
\text { larvae of the geohelminth parasites were recovered using zinc sulphate flotation } \\
\text { technique. The respective prevalence of geohelminth ova recovered from dumpsite } \\
\text { soil samples are Ascaris lumbricoides } 28(13.5 \%) \text {, Hookworm specie } 15(7.2 \%) \text {, } \\
\text { Trichuris trichiura } 9(4.3 \%) \text { and Strongyloides stercoralis } 7(3.4 \%) \text {. Dump soil } \\
\text { contamination with the helminthes ova was higher in Iloro } 20(31.3 \%) \text {, followed by } \\
\text { Molete } 7(29.2 \%) \text {, Igbara-odo road } 9(28.1 \%) \text {, and Owode } 13(27.1 \%) \text {, then Central } \\
\text { town 10(25.0\%). The respective prevalence of the four }(4) \text { ova of intestinal } \\
\text { helminth recovered from dumpsite stool samples are Ascaris lumbricoides } \\
4(25.0 \%) \text {, Hookworm } 2(12.5 \%) \text {, Trichuris trichiura } 1(6.3 \%) \text { and Taenia spp } \\
1(6.3 \%) \text {. There was a significant difference (P<0.05) in geohelminth ova } \\
\text { prevalence encountered in the study area. The study discussed the prevalence and } \\
\text { health implications of human intestinal helminth ova in refuse dumpsites in Igbara- } \\
\text { oke, Ifedore Local Government Area. Findings call for an improvement in the basic } \\
\text { environmental and sanitary conditions, adequate waste management services and } \\
\text { health education on personal hygiene. }\end{array}$} \\
\hline & \\
\hline & \\
\hline & \\
\hline & \\
\hline Article Info & \\
\hline & \\
\hline & \\
\hline & \\
\hline & \\
\hline
\end{tabular}

\section{Introduction}

Geohelminths or Soil-transmitted helminths (STHs) are a group of parasites that infect the gastrointestinal tracts of humans. These are Hookworm spp, Ascaris lumbricoides, Trichuris trichiura and Strongyloides stecoralis. They have a direct life cycle and can either be transmitted by eggs or larvae present in human faeces present in contaminated soil, food stuffs and water supplies mostly in areas where sanitation is poor. The adult worms are essentially parasites of human, but also infect domesticated mammals. The juveniles are the infective forms and they undergo tissuemigratory stages during which they invade vital organs such as lungs and liver. The geohelminths together presents an enormous infection burden on humanity, amounting to 135,000 deaths every year (Bethony et al., 2006). More than 1.5 billion people or $24 \%$ 
of the world's population are infected with soil- transmitted helminth infections worldwide (WHO 2013). The global burden of soil-transmitted helminthes (STHs) infection according to Murray et al., (2013, and Brooker, (2006) is estimated at between 5 and 39 million disability-adjusted life years. Geohelminths infection is a problem of children from rural areas of developing countries and in Nigeria; it was an important cause of morbidity in school age children, who harbours the highest intensity of worm infection (Ukpai, 2003). Transmissions of STHs occur via contact with contaminated soil (hookworm) or consumption of eggcontaminated foods (A. lumbricoides and $T$. trichiura) (Vandemark et al., 2010).

\section{Materials and Methods}

This study was undertaken to determine the dispersion of soil-transmitted helminth ova in refuse dump soils around major areas in Igbara-oke, Ifedore Local Government Area, Ondo State. Igbara-oke, on latitude of 7.4, $7024^{\prime} 0.0^{\prime \prime} \mathrm{N}$ and longitude of $5.05,5^{\circ}$ 2'59.9994" E, is the head quarter of the Local Government Area with a population of 176,372 as at 2006 (National Population Commission, 2009). Refuse are dumped at designated areas in the town and around the houses. On specific days, refuse are cleared by the Local Government Waste management Board. However stools are still promiscuously and indiscriminately dumped on these soils.

\section{Collection of Soil Samples}

Samples were collected from Owode, Iloro, Molete, Oja Oba and Igbara-Odo road. At least five different locations from each refuse dumpsite were selected for soil sample collection. A total of 208 soil samples were collected using the method of Stojčević et al., (2010). Soil was taken from at least $2 \mathrm{~cm}$ deep into the soil using a hand trowel sterilized by cleaning with $95 \%$ ethanol. Soil samples were placed into labeled screw caped bottles and transported to Microbiology laboratory of The Federal University of Technology and they were analysed for the presence of human intestinal geohelminth ova or larvae.

\section{Parasitological Analysis of Soil Samples}

Zinc sulphate flotation technique of Ogbolu et al., (2011) was used to examine the soil samples. Each soil sample was sieved to remove debris and coarse particles. About 5 grams of the soil was mixed thoroughly with $10 \mathrm{mls}$ of distilled water, strained into test tube and centrifuged at $2500 \mathrm{rpm}$ for 3 minutes. The supernatant was decanted and the sediment was mixed with $10 \mathrm{mls}$ zinc sulphate solution of $33 \%$ weight per volume (1.18-1.20 specific gravity). This was added to the brim of the test tube and allowed to stand for few minutes with a cover slip placed on the tube to collect floating ova. The cover slip was carefully removed and placed faced down on a clean glass slide for examination under the $\mathrm{x} 10$ and $\mathrm{x} 40$ objective lens.

\section{Data Analysis}

Data obtained were subjected to statistical analysis of variance (ANOVA) and the means were compared at $95 \%$ level of significance $(\mathrm{p} \leq 0.05)$ using the New Duncan Multiple Range test.

\section{Results and Discussion}

Table 1 shows the recovery of geohelminths ova and larvae from dumpsite soils at different areas in Igbara-oke. Ova/larvae of parasites encountered were Ascaris lumbricoides, Trichuris trichiura, hookworm, Strongyloides stecoralis. The distribution of the geohelminths ova were significantly different $(\mathrm{P}<0.05)$. 
Table.1 Recovery of Geohelminths Ova/Larvae from Dumpsite Soils at Different Areas in Igbara-oke

\begin{tabular}{ccccccc}
\hline \multicolumn{7}{c}{ Ova/cyst of Parasite encountered } \\
Study area & $\begin{array}{c}\text { Number of } \\
\text { soil sample }\end{array}$ & A. lumbicoides & T. trichiura & Hookworm & S. stercoralis & Total \\
\hline Iloro & 64 & 10 & 3 & 5 & 2 & 20 \\
Owode & 48 & 6 & 2 & 3 & 3 & 13 \\
Central & 40 & 5 & 1 & 2 & 1 & 1 \\
Molete & 24 & 3 & 2 & 2 & 7 & 9 \\
Igbara-odo road & 32 & 4 & $9(4.3)$ & $15(7.2)$ & $7(3.8)$ & 59 \\
\hline Total (\%) & 208 & $28(13.5)$ & & & & \\
\hline
\end{tabular}

Table.2 Prevalence of the Geohelminths Ova in Soil in the Study Area

\begin{tabular}{llll}
\multicolumn{1}{c}{ Study area } & Number of soil sample & Number of Ova & Prevalence $(\%)$ \\
Iloro & 64 & 20 & 31.3 \\
Molete & 24 & 7 & 29.2 \\
Igbara-odo road. & 32 & 9 & 28.1 \\
Owode & 48 & 13 & 27.1 \\
Central town & 40 & 10 & 25.0 \\
\hline Total & 208 & 59 & 28.4 \\
\hline
\end{tabular}


Ascaris lumbricoides has the highest prevalence of (13.5\%) followed by hookworm (7.2\%), Trichuris trichiura (4.3\%), and Strongyliodes stercoralis has the least prevalence of $3.4 \%$.

Table 2 shows the prevalence of the parasites ova in refuse dumpsite soils in each study area. Dispersion of human intestinal helminth ova in soil was found to be significanlyt difference $(\mathrm{P}<0.05)$ in the selected areas. The prevalence of soil contamination with helminth ova high in Iloro 20(31.3\%), followed by Molete $7(29.2 \%)$, Igbara-odo road $9(28.1 \%)$, Owode 13(27.1\%), and 10(25.0\%) in the Central town. The overall prevalence of soil contamination with geohelminth ova in the study area was $28.4 \%$.

The recovery of geohelminths ova from refuse dumpsites revealed that human intestinal geohelminth parasites could be prevalent in the study area. The result is similar to the findings of other studies that have been reported in Nigeria, Nwoke et al., (2013) and Ugbomoiko et al., (2006).

The widespread contamination of soil with eggs and larvae of human intestinal parasites is epidemiologically significant. The high prevalence of Ascaris lumbricoides observed in this study probably be connected with the ubiquitous nature and resistance of $A$. lumbricoides ova to harsh environmental conditions as reported by Bethony et al., (2006).

The high prevalence of hookworm observed in this study may have been favoured by physical and chemical composition of the soil, poor hygiene, and indiscriminate disposal of excreta and lack of access to health care services. This observation is in line with findings of Brooker, et. al. (2006).The observed prevalence of Trichuris trichiura in this study may be attributed to the differences in egg viability. The eggs of $T$. trichiura are less resistance to environmental conditions like exposure to sunlight or drying (Crompton, 1999). The observed prevalence of Strongyloides stercoralis agrees with the opinion of Hotez et al., (2003), that the moisture films of contaminated soils are favourable condition for viability of the eggs until contact with suitable host is made. The observation also agrees with previously reported findings in Nigeria by Ogbolu et al., (2011) and Dada (2016).

Parasitic infections abound in unsanitary surroundings with constant faecal pollution of soil. This study has revealed the potential health risk of contracting intestinal helminth parasites in soil around refuse dumpsites in the study area. Purchase of more waste disposal vehicles, adequate staffing and mounting public enlighten campaign on media are some of the public investments on sanitation that is essential to, protect individuals, control geohelminths and other sanitary related infectious diseases.

\section{References}

Bethony, J., Brooker, S., Albonico, M., Geiger, S.M., Loukas, A., Diemert, D., Hotez, P.J. (2006). "Soil-transmitted helminth infections: ascariasis, trichuriasis, and hookworm". The Lancet.367(9521): 1521-1532.

Brooker, S., Clements, A. and Bundy, D.A.P. (2006).“Global epidemiology, ecology and control of soil-transmitted helminth infections."Advanced Parasitology. 62:223-265.

Cooper, P.J. (2009). "The interactions of parasites with allergy."Current Opinion in Allergy and Clinical Immunology.9:2937.

Crompton, D.W.T. (1999). "How much human helminthiasis is there in the 
world?" Journal of Parasitology. 85:397403.

Crompton, D.W.T. (2001). " Ascaris and ascariasis." Advanced Parasitology, 48:285-375.

Dada, E. O. (2015). Study on the Ectoparasites and Haemoparasites of Domestic Rats in parts of Akure South Local Government Area of Ondo State. International Journal of Clinical Chemistry and Laboratory Mediciene. 1(1): 1-5.

Hotez, P.J., da Silva, N., Brooker, S. and Bethony, J. (2003)." Soil Transmitted Helminth Infections: The Nature, Causes and Burden of the Condition. Working Paper No.3, Disease Control Priority Project.Behesda, Maryland: Fogarty International Center, National Institute, page 458.

Murray, C.J., Vos, T., Lozano, R., Naghavi, M. and Flaxman, A.D. (2013). "Disability-adjusted life years (DALYs) for 291 diseases and injuries in 21 regions, 1990-2010: a systematic analysis for the Global Burden of Disease Study 2010".Lancet. 380: 2197-2223.

Nwoke, E.U., Ibiam, G.A., Odikamnoro, O.O., Umah, O.V., Ariom, O.T. and Orji, I. (2013)."Examination of soil samples for the incidence of geohelminth parasites in Ebonyi north-central area of Ebonyi State, south-east of Nigeria."Archives of Applied Science Research, 5(6):41-48.

Ogbolu, D.O., Terry Alli, A.O., Amoo, A.O.J., Olaosun, I.I., Ilozavbie, G.W. and Olusoga-ogbolu, F.F. (2011). High-level parasitic contamination of soil sample in Ibadan metropolis. African Journal of Medicine and Medical Sciences.40: 8587.
Stojčević, D., Sušić, V. and Lućinger, S. (2010).Contamination of soil and sand with parasite elements as a risk factor for human health in public parks and playgrounds in Pula, Croatia. Veterinarski Achiv. 80(6): 733-742.

Stoltzfus, R.J., Dreyfuss, M.L., Chwaya, H.M., and Albonico, M. (1997). "Hookworm control as a strategy to prevent Iron Deficiency Anaemia".Nutrition Reviews. 55:223-32.

Ugbomoiko, U.S., Onajole, A.T. and Edungbola, L.D. (2006)."Prevalence and Intensity of geohelminths infection in Oba-Ile Community of Osun State, Nigeria.Nigerian Journal of Parasitology.27:62-67.

Ukpai, M. (2003).“The prevalence of gastro intestinal tract parasites in Primary school children in Ikwuano local government area of Abia State, Nigeria.Nigerian Journal of Parasitolog. 240:129-36.

Vandemark, L.M., Jia, T.W., and Zhou, X. N.(2010). "Social science implications for control of helminth infections in Southeast Asia". Advanced Parasitology.73:137-170.

World Health Organization (2006). Preventive Chemotherapy in Human Helminthiasis: Coordinated Use of Antihelminthic Drugs in Control of interventions: a Manual for Health Professionals and Programme Managers. WHO Press, World Health Organization, Geneva, Switzerland. pp. 1-61

World Health Organization, (2013)."Soiltransmitted helminth infections" factsheet, No.366.Retrieved 2014-01-09.

\section{How to cite this article:}

Dada, E. O. and Egbunu, A. A. 2016. Dispersion of human intestinal Geohelminth ova in selected refuse dumpsites in Igbara-Oke, Ifedore, Local Government Area, Ondo State, Nigeria Int.J.Curr.Microbiol.App.Sci.5(4): 924-928. doi: http://dx.doi.org/10.20546/ijcmas.2016.504.104 